\title{
THE IMPACT OF USING LEAFCUTTING BEES (Megachilidae hymenoptera) WITH DIFFERENT FERTILIZATION TREATMENTS ON ALFALFA SEED PRODUCTION
}

\author{
Mohamed A. Shebl ${ }^{1,2, *}$, Soliman M. Kamel ${ }^{1}$, Talaat A. Abu Hashesh ${ }^{1}$, Mohamed A. \\ Osman $^{1}$ \\ ${ }^{1}$ Dept. of Plant Protection, Faculty of Agriculture, Suez Canal University, Ismailia, \\ EGYPT. ${ }^{2}$ Entomological Laboratory, Graduate school of Bioresource and Bioenvironmental, \\ Kyushu University, Fukuoka, 812-8581, Japan. \\ * Corresponding author: mohamedshebl2002@hotmail.com
}

\begin{abstract}
Alfalfa, Medicago sativa (L, 1753), one of the most important forage crops in the world; leafcutting bees which belong to Family Megachilidae are very promising pollinator of Alfalfa is USA and Canada. Different lefacutting natural nests were discovered in Ismailia (east part of Egypt). Artificial polystyrene foam nests were used for bees nesting; it is easy to manage and handle it in alfalfa fields. Different fertilization treatments were carried out for testing their impact on alfalfa seed production in the presence of artificial nests. The seed production depends basically on the pollination of leafcutting bees (tripping mechanism) more than fertilization treatment; we found no significant differences between different fertilization treatments. It is highly recommended to use phosphorus and potassium fertilizers during the blooming season synchronized with leafcutting bees.
\end{abstract}

Keywords: Pollination, Alfalfa, Seed Production, Leafcutting bees

\section{INTRODUCTION}

Afalfa, Medicago sativa (L, 1753), is a high quality forage and green manure crop that originated in the Middle East. Currently there are 80-120,000 hectares of alfalfa planted in Egypt, and acreage is rising each year especially in the newly reclaimed lands (Shebl et al., 2008). Entomologists and agronomists have studied a wide range of alfalfa seed production issues, especially those related to pollinators such as the alfalfa leafcutting bee Megachile rotundata (Fabricius, 1793). Alfalfa seed production in the western United States relies exclusively on irrigation. Because alfalfa seed producers were relatively late in adopting commercial pollination practices to their management practices, there are still many unanswered questions concerning leafcutter bee management (Olmstead and Wooten, 1987). Previously, the alkali bee Nomia melanderi Cockerell, 1906 was also used for pollination but the leafcutting bee has to a large extent replaced it as the main pollinator for alfalfa seed production 
(Baird et al., 1991; Seed Trade News, 1995). Mud walls nests of leafcutting bees were discovered on eastern part of Egypt and artificial nests were used as bee traps in the spring season. Nesting activities of Megachile uniformis Mitchell, 1929 started shortly after the emergence of the females, i.e. during the mating period, and continued to the end of the activity season. The emergency of bees started on 10 April in the two seasons of 2001, and 2003. Females were active from 10 April 10 to 6 June. A female usually hovers around the nests to select a suitable nesting site for herself. After selecting the nest, she starts cleaning it before inhabiting it (Shoukry et al., 2004). Flower production and pollination models have been developed in order to try and understand the relationship between bee population, rate of bloom, and the timing within the season of maximum pollination (Strickler, 1997). Alfalfa requires high levels of soil nutrients to maintain plant populations and achieve maximum yields (Anonymous, 1982; Goplen et al., 1982). Alfalfa grown for seed may not require the same levels of nutrition as for forage, because export of nutrients from the field is much lower. The deep roots of alfalfa are also able to access nutrients that cannot be reached by shallower-rooted crops (Gossen et al., 2004).

Alfalfa has lower root density than many grasses and a deeper rooting zone $\mathrm{P}$ and $\mathrm{K}$ application increase root growth, enabling roots to obtain moisture and nutrients from greater volume of soil. $\mathrm{P}$ Functions in Plants; energy storage and transfer, phosphate compounds are "energy currency" (such as ADP and ATP), structural component of biochemicals, seed formation, calcium and magnesium phytate, maintenance and transfer of genetic code, root growth, rapid crop establishment, early maturity, quicker recovery. Balanced $\mathrm{P}$ and $\mathrm{K}$ nutrition is essential for optimal yields and stand maintenance, proper attention to all nutrients is required for healthy plants and high yield levels. Phosphorus and $\mathrm{K}$ fertilization increases alfalfa (Medicago sativa L.) yield and stand persistence, but the changes in yield components as affected by $\mathrm{P}$ and $\mathrm{K}$ fertility level are not known. (Berg et al., 2005). Higher soil $\mathrm{P}$ concentrations increased the number of nodules on alfalfa roots at three soil moisture contents (dry, moist, and wet). An adequate $\mathrm{P}$ supply is essential for proper $\mathrm{N}$ fixation and protein production, which both impact the quantity and quality of the alfalfa hay (Azcon et al., 1988).

Our hypothesis is that $\mathrm{P}$ and (or) $\mathrm{K}$ fertilization will increase one or more alfalfa seed production, and seeds quantity responses may change with different fertilization treatment. The objectives of this study were to determine the impact of $\mathrm{P}$ and $\mathrm{K}$ fertilization with leafcutting bees on alfalfa seed production. We tested before the impact of alfalfa leafcutting bees only on the seed production of alfalfa but it is very important to recommend the farmers too with different fertilization treatment during the seed production season.

\section{MATERIAL AND METHODS}

\section{Artificial nesting of leafcutting bees}

Since 1997, every year artificial foam nests were made as a trap for leafcutting bees. These artificial foam nests were distributed in the natural nest of bees. These bees are easily managed and renesting in straws, wooden boards and styrofoam nesting blocks. 
The artificial material used for nesting bees was polystyrene. The nests consist of 50 pieces of foam, each piece $50 \mathrm{~cm}$ long, $12 \mathrm{~cm}$ width and $2 \mathrm{~cm}$ thick. Each piece of foam have 26 holes of $10 \mathrm{~cm}$ depth and $6 \mathrm{~mm}$ diameter. After sticking the pieces upon each other, holes are created in this block and the shelter was performed. Straws of paper tubes $10 \mathrm{~cm}$ in length and $5.2 \mathrm{~mm}$ internal diameter, one tube for each hole. The artificial nests moved to the sites of natural nests for suing it as a trap of bees from April until June for suing it in the following year. The natural nests were scattered in different villages around El-Tal El-kebear. These villages were El-Tal El-kebear, El-Kssasin and El Balwa (30- $40 \mathrm{~km}$ far from Ismailia) (Kamel et al., 2007) (Figure 1). The foam nests protected from any pests and moved to the alfalfa field (on the eastern part of the field in the front of the sun) at the beginning of spring season. The bee emergency usually synchronized with alfalfa blooming season (April-May).

\section{Experimental field preparation}

In the beginning of October 2005, 2006 and 2007 the experimental field of the bees research unit, Suez Canal University, Ismailia was prepared for alfalfa seed cultivation. The variety used was Ismailia 1, produced by the Agricultural experimental station in Ismailia. The grown distance between the plants was 30 $\mathrm{cm}$ and there were a total number of 1200 plants in the field. Normal nitrogen fertilizer was added to the field (Figure 2).

\section{Population of Megachile minutissima on alfalfa flowers}

Samples of bees were taken by a sweeping net in the experimental field of alfalfa, 25 double strokes per sweep. Samples were taken three times a day of work at $10 \mathrm{am}, 1 \mathrm{pm}$ and $3 \mathrm{pm}$ respectively. This was repeated every 7 to 10 days from the beginning of blooming till the end of the season.

Numbers of bees were recorded and bees were released again into the field for maintaining the population of bees till the end of the season.

\section{Studies about the effect of different chemical fertilizers on alfalfa seed production}

To study the effect of different chemical fertilizers on alfalfa seed production, the field at the experimental farm was divided into 12 treatments, 3 plots for each treatment. All 36 plots were randomly distributed in the field.

Different treatments were recorded in Table 1, applying fertilization treatments of phosphorus $\left(\mathrm{P}_{2} \mathrm{O}_{5}\right)$ and potassium $\left(\mathrm{K}_{2} \mathrm{O}\right)$.

\section{Seasonal blooming of alfalfa and the yield of seeds production}

To study the seasonal blooming of alfalfa, 36 of plants were labeled (3 plants/treatment). Each plant was subject to record the following points:

1) Number of total flowers

2) Number of total pods

3) Number of seeds in 100 pods.

4) Weight of 100 seeds.

5) Average seed production per plant

\section{Statistical Analysis}

The data were analyzed by using CoStat statistical method analysis. 
Table 1: Different fertilization treatments

\begin{tabular}{ll}
\hline Number of treatment & Fertilization treatment \\
\hline F1 & Control \\
F2 & $300 \mathrm{~g}$ Phosphorus 5.2 \\
F3 & $600 \mathrm{~g}$ Phosphorus 5.2 \\
F4 & $900 \mathrm{~g}$ Phosphorus 5.2 \\
F5 & $300 \mathrm{~g}$ potassium 2 \\
F6 & $450 \mathrm{~g}$ potassium 2 \\
F7 & $300 \mathrm{~g}$ Phosphorus $5.2+300 \mathrm{~g}$ potassium 2 \\
F8 & $300 \mathrm{~g}$ Phosphorus $5.2+450 \mathrm{~g}$ potassium 2 \\
F9 & $650 \mathrm{~g}$ Phosphorus $5.2+300 \mathrm{~g}$ potassium 2 \\
F10 & $600 \mathrm{~g}$ Phosphorus $5.2+450 \mathrm{~g}$ potassium 2 \\
F11 & $900 \mathrm{~g}$ Phosphorus $5.2+300 \mathrm{~g}$ potassium 2 \\
F12 & $900 \mathrm{~g}$ Phosphorus $5.2+450 \mathrm{~g}$ potassium 2 \\
\hline
\end{tabular}

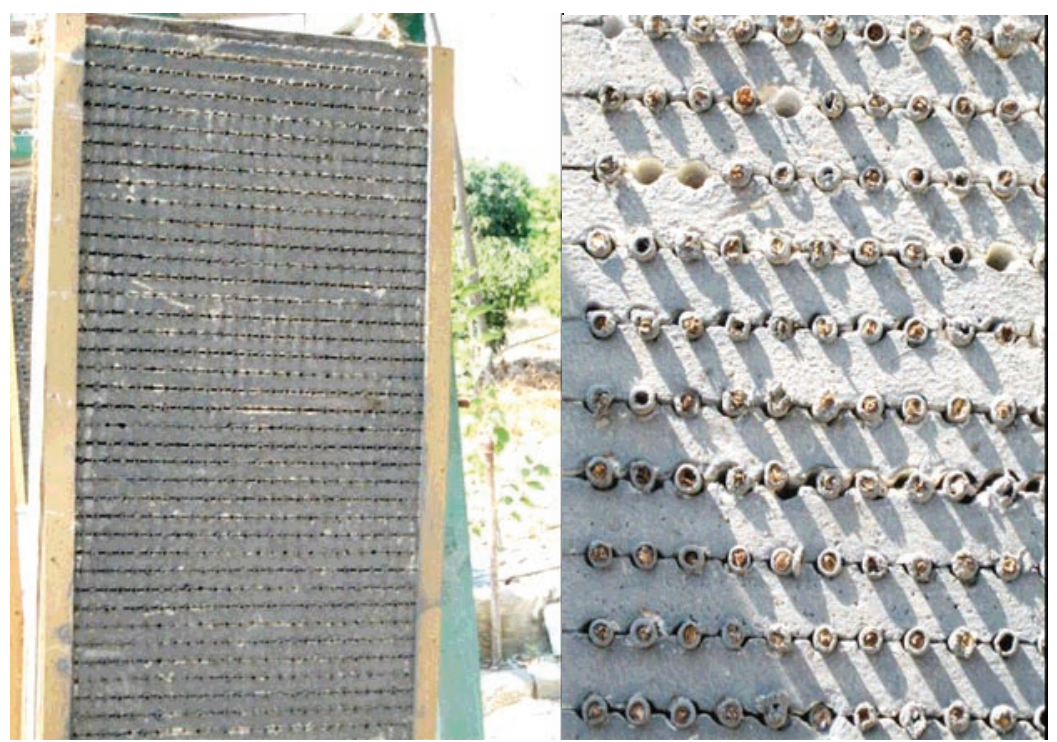

Figure 1: Alfalfa leafcutting bees artificial nests 
Impact of leafcutting bees on alfalfa seed production, Shebl et al.

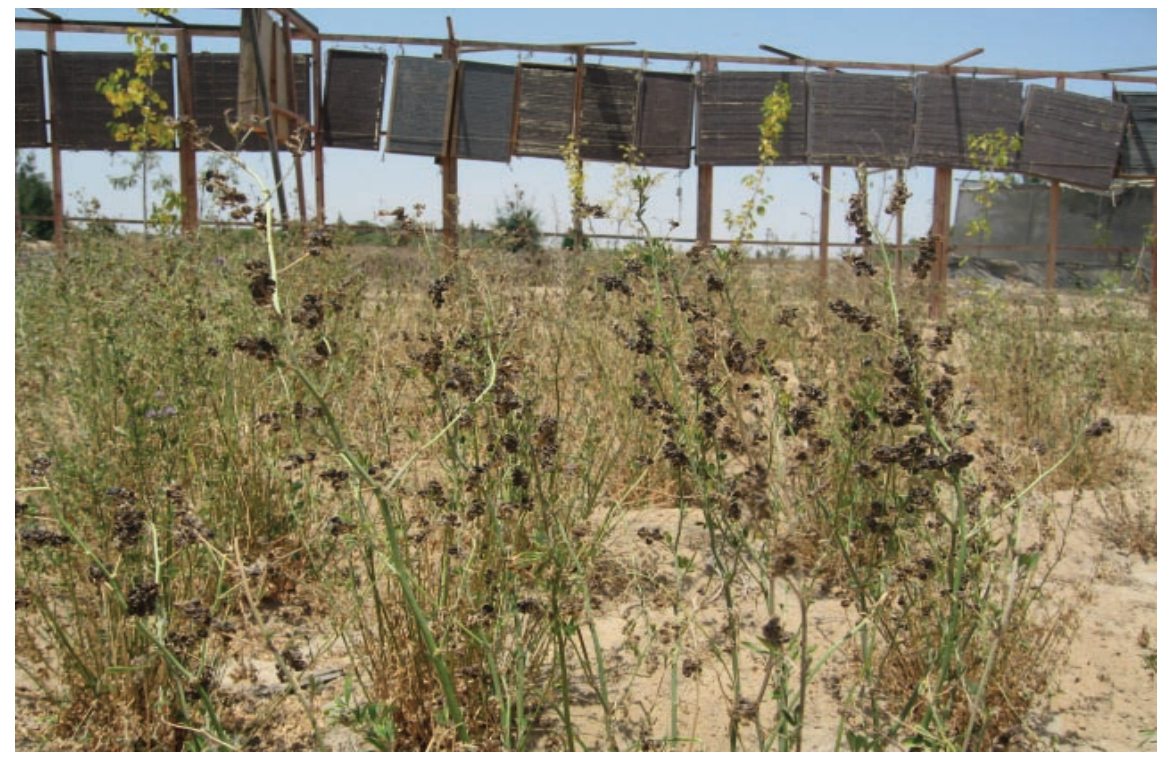

Figure 2: Alfalfa experimental field with leafcutting bees artificial nests

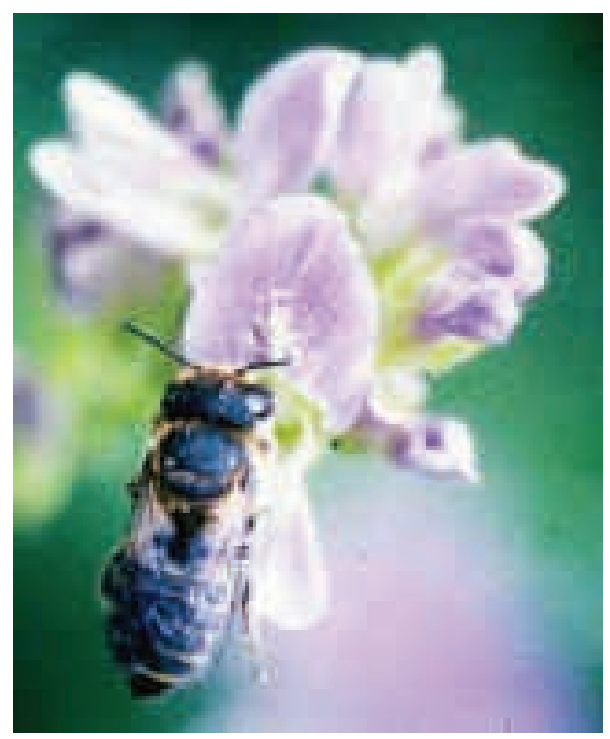

Figure 3: Leafcutting bees tipping alfalfa flower 


\section{RESULTS AND DISCUSSION}

Fertilization with $\mathrm{P}$ and $\mathrm{K}$ has long been known to improve persistence and yield of alfalfa (Markus and Battle, 1965; Smith, 1975), but the physiological and morphological mechanism responsible for yield increases remains unclear. There was no role for the type and the amount of chemical fertilization to attract bees, bees can visit any alfalfa flowers with no effect of type of fertilization. It is though that yield had tapered off with the single event broadcast application, the earlier yield increase over more frequent application was enough to produce greater overall yield.

The "tapering off" effect of the onetime application was minimized by banding fertilizer, thus the pre plant banded $600 \quad \mathrm{lb} \quad \mathrm{P}_{2} \mathrm{O}_{5} / \mathrm{A}$ application produced the greatest yield. Other studies shown that in some soils a large single pre plant application of $\mathrm{P}$ fertilizer to alfalfa can be effective for multiple years, and that banding $\mathrm{P}$ can provide additional yield benefit (Mullen et al., 2000). Similar results have been obtained from Alberta, Canada. The duration of the adequate $\mathrm{P}$ availability will depend on the amount initially applied and the soil chemical reactions that occur to reduce the plant availability of the applied $\mathrm{P}$ (Malhi et al., 2001). Average alfalfa hay yields were the same between the large one-time $\mathrm{P}$ application or the smaller annual $\mathrm{P}$ applications. The most important process for alfalfa pollination is "tripping". Alfalfa seed production is enhanced by cross-fertilization which is largely achieved by bees. The anthers (pollen source) and stigma (pollen receptacle) of an alfalfa flower are exposed only when flowers is "tripped".
If a flower is not tipped, then pollination cannot take place. Tripping occurs when the action of a flower-visiting bee release pressure on interlocking keel petals, abruptly snap upward from within the keel (Figure 3).

The seasonal abundance of leafcutting bees during the blooming season started from April until end of May. The total number of emerged bees during 2005 was 765 individual (about 1 male to 1 female).

In 2006 the total number was 572 but most of the population was females. Observation indicated that males start flying a few days before females and have a small role in alfalfa flower pollination. The different fertilization treatments have not demonstrated a big influence on the seed production. Management strategies to increase the seed yield a) by placing bee shelters closer and b) cultural practices that increase total flower production. Both these factors will increase tripped flowers and thus will have a positive effect on yield. In addition, warmer temperatures during the growing season, particularly in the early stages of plant growth is shown to not only increase tripped flowers but also reduce the time when the maximum tripped flowers occur. The latter appears to have a significant influence on cumulative tripped flowers and thus the total seed yield (Don Breazeale, 2008).

The leafcutting bees have a great impact on the seed production of alfalfa more than fertilization treatments (Shebl et al., 2008). But generally we recommend using adequate amount of phosphorus and potassium treatment synchronized with using leafcutting bee artificial nests. 
Impact of leafcutting bees on alfalfa seed production, Shebl et al.

Table 2: The number of flowers, pods, average No. of seeds /100 pods, dry weight of 100 seeds and average weight seeds per one plant in 2005.

\begin{tabular}{lccccc}
\hline Treatment & $\begin{array}{c}\text { Average N } \\
\text { of flowers }\end{array}$ & $\begin{array}{c}\text { Average } \mathbf{N}^{\circ} \\
\text { of pods }\end{array}$ & $\begin{array}{c}\text { Average No } \\
\text { of seeds } \\
\text { /100 pods }\end{array}$ & $\begin{array}{c}\text { Dry } \\
\text { weight of } \\
\mathbf{1 0 0} \text { seeds } \\
\text { (g) }\end{array}$ & $\begin{array}{c}\text { Average } \\
\text { weight } \\
\text { seeds per } \\
\text { one plant } \\
\text { (g) }\end{array}$ \\
\hline F1* & $18.6 \mathrm{a}$ & $9.3 \mathrm{a}$ & $351 \mathrm{a}$ & $0.23 \mathrm{abc}$ & $2.05 \mathrm{a}$ \\
F2 & $21 \mathrm{a}$ & $12 \mathrm{a}$ & $317.3 \mathrm{a}$ & $0.2 \mathrm{bc}$ & $2.65 \mathrm{a}$ \\
F3 & $19.3 \mathrm{a}$ & $10.6 \mathrm{a}$ & $381.3 \mathrm{a}$ & $0.23 \mathrm{abc}$ & $3.5 \mathrm{a}$ \\
F4 & $21.6 \mathrm{a}$ & $9.6 \mathrm{a}$ & $355.6 \mathrm{a}$ & $0.24 \mathrm{abc}$ & $3.32 \mathrm{a}$ \\
F5 & $20.6 \mathrm{a}$ & $9.6 \mathrm{a}$ & $347.6 \mathrm{a}$ & $0.21 \mathrm{abc}$ & $2.48 \mathrm{a}$ \\
F6 & $22 \mathrm{a}$ & $11 \mathrm{a}$ & $405.3 \mathrm{a}$ & $0.21 \mathrm{abc}$ & $2.97 \mathrm{a}$ \\
F7 & $20 \mathrm{a}$ & $8.6 \mathrm{a}$ & $414.6 \mathrm{a}$ & $0.21 \mathrm{abc}$ & $3 \mathrm{a}$ \\
F8 & $21 \mathrm{a}$ & $10 \mathrm{a}$ & $434.3 \mathrm{a}$ & $0.24 \mathrm{ab}$ & $3.23 \mathrm{a}$ \\
F9 & $21.3 \mathrm{a}$ & $9.3 \mathrm{a}$ & $330.3 \mathrm{a}$ & $0.23 \mathrm{abc}$ & $2.5 \mathrm{a}$ \\
F10 & $23.6 \mathrm{a}$ & $12 \mathrm{a}$ & $369.3 \mathrm{a}$ & $0.20 \mathrm{c}$ & $2.13 \mathrm{a}$ \\
F11 & $19 \mathrm{a}$ & $9.3 \mathrm{a}$ & $388.6 \mathrm{a}$ & $0.24 \mathrm{abc}$ & $2.33 \mathrm{a}$ \\
F12 & $20.6 \mathrm{a}$ & $10.6 \mathrm{a}$ & $364 \mathrm{a}$ & $0.25 \mathrm{a}$ & $2.14 \mathrm{a}$ \\
L.S.D at 5\% & 5.2 & 3.4 & 101.7 & 0.04 & 1.3 \\
\hline
\end{tabular}

Table 3: The number of flowers, pods, average No. of seeds /100 pods, dry weight of 100 seeds and average weight seeds per one plant 2006.

\begin{tabular}{lccccc}
\hline Treatment & $\begin{array}{c}\text { Average No } \\
\text { of flowers }\end{array}$ & $\begin{array}{c}\text { Average } \mathbf{N}^{\circ} \\
\text { of pods }\end{array}$ & $\begin{array}{c}\text { Average No } \\
\text { of seeds } \\
\text { /100 pods }\end{array}$ & $\begin{array}{c}\text { Dry } \\
\text { weight of } \\
\mathbf{1 0 0} \text { seeds } \\
\text { (g) }\end{array}$ & $\begin{array}{c}\text { Average } \\
\text { weight } \\
\text { seeds per } \\
\text { one plant g } \\
\text { (g) }\end{array}$ \\
\hline F1 ${ }^{*}$ & $21.3 \mathrm{~b}$ & $9.6 \mathrm{a}$ & $405.6 \mathrm{a}$ & $0.26 \mathrm{a}$ & $10 \mathrm{a}$ \\
F2 & $19 \mathrm{~b}$ & $10.6 \mathrm{a}$ & $561.6 \mathrm{a}$ & $0.22 \mathrm{ab}$ & $9.5 \mathrm{a}$ \\
F3 & $20.3 \mathrm{~b}$ & $10 \mathrm{a}$ & $470 \mathrm{a}$ & $0.24 \mathrm{ab}$ & $5.7 \mathrm{a}$ \\
F4 & $20.3 \mathrm{~b}$ & $11 \mathrm{a}$ & $593 \mathrm{a}$ & $0.25 \mathrm{ab}$ & $11.6 \mathrm{a}$ \\
F5 & $26.3 \mathrm{a}$ & $9.6 \mathrm{a}$ & $519.3 \mathrm{a}$ & $0.22 \mathrm{ab}$ & $10.6 \mathrm{a}$ \\
F6 & $21.6 \mathrm{~b}$ & $10.3 \mathrm{a}$ & $485 \mathrm{a}$ & $0.22 \mathrm{ab}$ & $8.6 \mathrm{a}$ \\
F7 & $19.3 \mathrm{~b}$ & $10.3 \mathrm{a}$ & $573.6 \mathrm{a}$ & $0.23 \mathrm{ab}$ & $8.7 \mathrm{a}$ \\
F8 & $19.6 \mathrm{~b}$ & $10.6 \mathrm{a}$ & $546 \mathrm{a}$ & $0.26 \mathrm{a}$ & $10.3 \mathrm{a}$ \\
F9 & $21.6 \mathrm{~b}$ & $10 \mathrm{a}$ & $503 \mathrm{a}$ & $0.25 \mathrm{ab}$ & $8.7 \mathrm{a}$ \\
F10 & $22.6 \mathrm{~b}$ & $10.6 \mathrm{a}$ & $517.3 \mathrm{a}$ & $0.21 \mathrm{~b}$ & $7.7 \mathrm{a}$ \\
F11 & $19.3 \mathrm{~b}$ & $10.3 \mathrm{a}$ & $547.3 \mathrm{a}$ & $0.25 \mathrm{ab}$ & $9.8 \mathrm{a}$ \\
F12 & $22.3 \mathrm{~b}$ & $10.6 \mathrm{a}$ & $517 \mathrm{a}$ & $0.25 \mathrm{ab}$ & $11.4 \mathrm{a}$ \\
L.S.D at 5\% & 3.1 & 2.2 & 213.2 & 0.04 & 5.9 \\
\hline
\end{tabular}




\section{ACKNOWLEDGMENTS}

Thanks for Bee Research Unit peoples at Faculty of Agriculture, Suez Canal University. My deep thanks for the chief editor and two anonyms referee of the journal for their comments. This study supported by Egyptian Academy for Science and Technology.

\section{REFERENCES}

Anonymous. 1982. Fertilizer practices for Saskatchewan. University of Saskatchewan, Saskatoon, SK.

Azcon, R., El-Atrach F., Barea J.M. 1988. Influence of mycorrhiza vs soluble phosphate on growth, nodulation, and N2 fixation in alfalfa under different levels of water potential. Biol. Fertil. Soils. 7, 28-31.

Baird, C.R., Mayer, D.F., Bitner, R.M. 1991. Pollinators: Western Region Extension Publication 12 (WREP 12).

Berg, W. K., Cunningham, S. M., Brouder, S. M., Joern, B. C., Johnson, K. D., Santini, J., Volenec, J. J. 2005. Influence of Phosphorus and Potassium on Alfalfa Yield and Yield Components. Crop Sci. 45, 297-304.

Breazeale D., G.. Fernandez, Narayanan, R. 2008. Modeling pollination factors that influence alfalfa seed production in NorthCentral Nevada. J. Cent. Eur. Agric. 9 (1), 107-116.

Goplen, B. P., Baenziger, H., Bailey, L. D., Gross, A. T. H., Hanna, M. R., Michaud, R., Richards, K. W., Waddington, J. 1982. Growing and managing alfalfa in Canada. Agric. Canada Publ. 1705/E (revised). Agriculture Canada, Ottawa, ON. 50 p.

Gossen, B. D., Ukrainetz H., Soroka, J. J. 2004. Effect of fertilizer on seed yield of alfalfa under irrigation in Saskatchewan. Can. J. Plant Sci. 84, 1105-1108.

Kamel, S. M., Abu Hashesh, T. A., Osman, M. A., Shebl, M.A. 2007. A new model of polystyrene foam for renesting leafcutting bees (Megachile spp., $\quad$ Megachilidae, Hymenoptera). Agric. Res. J., Suez Canal University. 7 (2), 97-101.
Markus, D.K., Battle, W.R. 1965. Soil and plant responses to long-term fertilization of alfalfa (Medicago sativa L.). Agron. J. 57, 613-616.

Malhi, S.S., Zentner, R.P., Heier, K. 2001. Banding increases effectiveness of fertilizer $P$ for alfalfa production. Nutr Cycl Agroecosyst. 59, 1-11.

Mullen, R.W., Johnson, G.V., Stritzke, J.F., Caddel, J.L., Phillips, S.B., Raun, W.R. 2000. Alfalfa yield response to method and rate of applied phosphorus. Better Crops. 84(3), 18-23.

Olmstead, A., Wooten, D. 1987. Bee Pollination and Productivity Growth: The Case of Alfalfa. Amer. J. Agr. Econ. 69(1), 56-63.

Seed Trade News. 1995. Use of the Alfalfa Leafcutter Bee Growing in California. 116, $\mathrm{N}^{\circ}$, pp: 14.

Shebl, M. A., Kamel, S. M., Abu Hashesh, T. A., Osman, M. A. 2008. The impact of leafcutting bees (Megachile minutissima, Megachilidae,Hymenoptera).Radoszkowski, 1876) artificial nest sites on seed production of alfalfa, Ismailia, Egypt. Agricultura J. 5, 3335 .

Shoukry, A., Kamel, S. M., Abo Hashesh, T. A., Aziz, A. R. 2004. The changes in the seasonal activity and nesting behavior of Megachile uniformis (A.) (Hymenoptera: Megachilidae) based on artificial nesting site data figures in Ismailia. Agric. Res. J., Suez Canal University. 3(1), 139-144.

Smith, D. 1975. Effects of potassium topdressing a low fertility silt loam soil on alfalfa herbage yields and composition and on soil K values. Agron. J. 67, 60-64.

Strickler, K. 1997. Seed and Bee Yields as a Function of Forager Population: Alfalfa Pollination as a Model System. Journal of the Kansas Entomological Society. 69(4), 201215. 